\title{
Best practice of digital government in emerging democracies: Illustrations, challenges and reflections of state building processes
}

\author{
Carl-Johan Sommar \\ Linköping University \\ Carl-Johan.sommar@liu.se
}

\author{
Aneta Kulanovic \\ Linköping University \\ Aneta.kulanovic@liu.se
}

\author{
Ahmed Kaharevic \\ Linköping University \\ Ahmed.Kaharevic@liu.se
}

\author{
Elin Wihlborg \\ Linköping University \\ Elin.Wihlborg@liu.se
}

\author{
Helena Iacobaeus \\ Linköping University \\ Helena.iacobaeus@liu.se
}

\begin{abstract}
Digital government applications and models often add layers to existing structures, organizations, and routines to facilitate public services. In most states digital government is thus added to established structures and organizations, but what happens when egovernment develop at as an integrated part of new state building? This is the overall question in this paper presenting an analysis of best practices of e-government in six countries in the Western Balkans - Albania, Bosnia and Herzegovina, Kosovo, Montenegro, North Macedonia and Serbia. The cases of best practice have been identified through an interactive research process, and analyzed through a combined lens of eGovernment stage-models and core public values. The analysis shows how new digital government applications and innovations are designed and used in new democracies as part of new state building structures. The findings indicate a lack of new institutional arrangements for digital government. Taken together it shows that the development of eGovernment in the Western Balkans follows a path-dependence of other states, in spite of the opportunities for more innovative and sustainable eGovernment by continuing the institutional reformation.
\end{abstract}

\section{Introduction}

In most states, digital government applications and models are added to already existing structures, organizations and routines for integrations and daily work. However, when new democratic governmental structures are built in a digital era, digital government models are available and the potential to build institutions in line with digital government models are more open. A key case for this argument is the advanced egovernment structure in Estonia. Their model for building a digital state after the independence in 1991 has become a role model for the new democracies, not least in the eastern Europe and Western Balkan [1, 2]. By pointing out that digitalization "[..] enhances our democratic values, respects our fundamental rights, and contributes to a sustainable, climate-neutral and resource-efficient economy" the European Commission [3] considers digital government-issues essential to strenghten governance structures across and beyond the EU27 member states.

Democratic governments are built on public values and the organization, including professional case workers, need to focus on and strive for all public values [4]. In this paper, we focus on three public values: duty-oriented, service-oriented and socially-oriented values. However, states have different resources and competences to develop new e-government and have to search for best practices within their situations and institutional arrangements. The development of digital government is often analyzed and discussed in relation to stages models, where an expected development would follow [5, 6, 7]. These models have been developed based on research in mature and stable states, but there are new challenges when digital government is developing in line with a new state building.

The region of Western Balkan consists of mainly former Yugoslavia states Bosnia and Herzegovina, Croatia, Kosovo, Montenegro, North Macedonia, and Serbia (except Slovenia) and also Albania. After the Yugoslavian war 1991-1995 and later in Kosovo 1998-1999, new state-building processes begun in the 
region. Being recreated recently, the countries of Western Balkan could have the digital government as a default mode for conducting governmental practices.

We turn to theories of e-government stage-models to categorize and analyze sets of participant-chosen e-government best practices across the six Western Balkan-countries. By doing so we consider best practices as a generally accepted superior method or technique that can be used as a learning opportunity for other authorities facing similar problems. [8] This paper builds on an interactive research design set in the format of the Summer Academy for Young Professionals funded by the Swedish Institute. The Summer Academy targets young professionals in public administration in the Western Balkan states to build knowledge and practices for increased efficiency, transparency, and resilience in public administration [9]. One focus area of the Swedish Institute is to "... contribute to the implementation of the governments priorities for the promotion of democracy" [10] including reforms through exchange and cooperation with Western Balkan. The research team arranged a module of the Summer Academy called Sustainable eGovernment for Resilient and Innovative Democratic Public Administration (SeGRID) [11]. Here we collaborated with professionals in public administration in all the Western Balkan states, except Croatia, and their selections and discussions of e-government best practices are the core of the analysis here.

\subsection{Aim and research questions}

This paper focuses on the adoption of digital government innovations in emerging democracies in the Western Balkan, as a part of new state building structures. The paper is organized around three research questions:

- What illustrations of best practices have professionals in public administration in Western Balkan identified?

- How is digital government developed from a stage value model perspective?

- What can we learn from the development of digital government in new states regarding stages in development processes and value orientation?

\section{Knowledge building through interactive approaches - Research design}

Our interactive approach builds on the problems and also the best practices identified by the participants in the course. The sample is based on cross-sectional selection conducted by the professionals, but has not been further validated. Plausible theoretical ideas are developed as a means for linking the problem to the development of guiding concepts that may solve it. Theorization is linked to critical, constructive theorization rather than providing normative models of how to do things in organizations [12]. Based on this approach we focus on how to learn for theorization and to give feedback for practices.

\subsection{Best practices provided by participants in the Summer Academy SeGRID}

The Summer Academy SeGRID has been arranged by the research team for a target groups of young professionals in Eastern Europe for four years. This year 2020, was the first time for the Western Balkan region and also the first time for a web-based module due to Covid-19. There were two webinars preparing the course. The course included ten online lectures with follow-up Q\&A-sessions and five interactive sessions focusing on challenges and opportunities. Sustainable e-Government for Resilient and Innovative Democratic Public Administration (SeGRID) [11], as the name implies, focuses on challenges and opportunities in e-government as the world around us is becoming more digital, knowing that Sweden is often seen as a forefront in digitalization of society in general and public services in particular [13].

The SeGRID participants represent a new generation of politicians, public servants, and civil society workers in the Western Balkans working with statelevel and regional/municipal-levels of government. In accordance with the application requirements set by the Swedish Institute, they are all under 35 years and had to have an English proficiency to enter the program. Through a personal application letter, they also had to show experience of and interest in digital government. The 30 participants had an occupation relating to public administration or policy making organizations. All participants had at least a bachelor's degree, but many also had a master's degree, some had two master's degrees, a handful were $\mathrm{PhD}$ students and two had finished their PhD degrees. The most frequent academic background was in the field of law. Out of all 30 participants, eleven came from Albania, four from Bosnia and Herzegovina, eight from Kosovo, two from Montenegro, four from North Macedonia and one from Serbia. Of these, nine were civil workers, eleven were public servants and three were policymakers. Two of the 30 participants did not attend the full course and are not included here.

The data used in this paper is the participants' own choice of an e-government best practice in their home country. In the first part of the best practice as- 
signment, the participants received guidance on the assignment and, as an illustration, were introduced to an example of best practice of digital government in Sweden. They had then a few weeks before the next session to select and make a presentation of their choice of best practice.

Before the seminar, they uploaded their presentations to the learning platform for the course. During the online session, the participants first presented and discussed their best practices in smaller groups, five groups with six participants from different countries. After these group discussions, we had a more general seminar pointing at general implications. At the end of each day, the participants wrote a concluding reflection essay summing lessons learned and best practices.

All presentations (mainly PowerPoint slides with audio) were uploaded to the learning platform. With the consent of all participants, we used their presentations as background data for this paper, in combination with notes from group discussions, seminar sessions and the participants' discussion papers.

\subsection{Analytical approach}

The analytical framework we have developed for this study (see table 1 below) allows for the characterization of various approaches to consider best practices in relation to the status of digital government in various states. The analysis has been made in several steps to categorize the best practices in relation to the stage models and values of digital government. Firstly, through the group discussions and seminar. Secondly, through a re-analysis by the research team to develope the analytical model by adding the value orientation to distinct forms of practices at the same stage. This analysis took place after the course module and included some follow-up questions and brief interviews with some of the participants. The authors are fully responsible for the results presented here, in spite of the interactive first part of the analysis.

\subsection{Limitations of the study design}

This study emerges from a collaborative educational context and the participants had applied to the course, thus they are not representing their countries but still key actors who can give relevant cases and information on the status of e-government in their countries. They provided insights and information that could be biased, but it would have been complicated to get access to this type of material and discussions through other types of research design, like interviews or a survey.

Another limitation of the research design is our use of the concept 'best practice'. There is a complex underlying normative ambition in searching for the best. This constraint was introduced and discussed already in our presentation of the collaboration around best practices. We presented the Swedish e-ID used for most digital government services to highlight the problematic concept of best practices. In spite of being generally seen as a very good practice there are studies pointing at the lack of usability for disabled, non-citizens and for those with cognitive disability [14]. By using this example, we asked the participants to choose e-government applications or e-services, that they consider especially good or "best" in their context and highlight challenges.

\section{Digital government development through stage models}

Digital government deployment is a part of each state's unique structure and institutional framing. Stage models have been used to describe the development of digital government and will structure our analysis in combination with a focus on values guiding each of the best practices.

\subsection{Building a Digital state}

States are governed within an institutional and bureaucratic structure that they set out [15]. To realize the potential of new digital technologies, Fountain [16] argues that the bureaucratic state change to evolve and adapt to exploit the possibilities of digital governance fully and fairly. Fountain [16] concluded that the real challenges were not in use of new technical applications at that mainly as 'a government on the web', but rather in overcoming the entrenched political and organizational structures within the state and its relations to the surrounding society. Thereby, she points at the importance of institutional development. This socio-technical approach acknowledges the complex nature of technology, politics, and institutional arrangements $[16,17]$.

\subsection{Digital government stages}

Stage models, or growth models, provide useful heuristics for categorizing of digital government initiatives and capabilities. Several scholars, e.g., Layne and Lee [5, 6] and Siau and Long [18], argue that the transformation of eGovernment development is stagewise and progressive. The evolutionary argument is that embedded and siloed governmental service delivery incrementally develop into comprehensive and cross-sectorial models with increased complexity and 
integration amongst and within governmental agencies [19].

Currently, there is a lack of consensus for the classification of stages. However, stage models tend to share similar impressions on the evolution of eGovernment as service provisioning through the use of ICT increase incrementally $[20,6]$. Through their seminal study of eGovernment projects in the US, Layne and Lee [5] argue that the first stage of providing e-services take place through cataloging, i.e., online presence and of providing governmental information online. Thereafter, e-government turns towards a transactional phase wherein the citizen can interact with the government through stove-piped services online, with vertical and horizontal integration. A similar view is proposed by Hiller \& Bélanger [21] and Bélanger \& Hiller [22], who argue that e-governments mature through five stages of transitions; beginning with the mere dissemination of information, and ending with e-government structures that facilitate democracy and public participation. From these perspectives, e-government bears an instrumental and technical connotation as phase transition depends on the underlying technical systems.

Owing to the technological focus, e-government stage models have become increasingly criticized as governments operate within a social setting [23]. Likewise, these models are ill-suited for studying emerging or new democracies, Joshi and Islam argue [24] and point at the need for softer non-technical aspects such as agency, values, or norms. Addressing the lack of agency, Andersen and Henriksen [25] contrast the aforementioned model by adopting a more citizencentered and process-oriented approach, leading to in the higher stages to a high degree of data mobility, cross-sectorial integration, and interactive case handling.

Klievink and Janssen [7] add to the debate on agency by presenting a five-stage model that relies on dynamic capabilities that further stage progression. By differentiating between organizational and national levels while applying the same logic and linear progression as previous scholars, Klievink \& Janssen [7] argue that the need for interdependencies and cooperation among governmental actors leads to integrated organizations.

Whereas early contributions, e.g., Layne and Lee [5], regarded stage transition as contingent upon maturity, later scholars have emphasized more dynamic accounts of progression. Later Lee [6, p. 229] stresses that "not every government has to go through stage one to stage five in terms of implementing e-Government related technologies or systems." More recently, this notion has been challenged by Rooks, Matzat, and Sadowski [26], who contend that the linear assumption of eGovernment development holds, i.e., that stageskipping does not occur.

\subsection{Values and digital government}

Governments are considered as a guarantor of public values [27] and the values are underpinning how public organizations and civil servants should interact with citizens, businesses, and other community actors when carrying out daily activities [28]. As these services are created and provided as a common good, public sector values need to be distinguished from their market counterparts as services catered have to foster and nurture aspects as, e.g., the rule of law, universal access, equality, transparency, and legitimacy. This is equally, or more important, in emerging democracies as these countries are transitioning through phases wherein values become institutionalized over time. Technology is value-laden and the use of ICT within government leads the inscribing or translation of public values into digital government.

Bannister [4] argues that the question is how digital government is properly designed within its bureaucratic system and thereby have the capacity to carry and express public value. These public values are guiding the digital government services and can be seen as duty-oriented values (the duty of public administrators to the government and the state), service-oriented (to provide a high level of service to citizens as well as the resilience such service requires, such as respect for the individual citizen and transparency) and socially-oriented (broader social goals such as inclusiveness or fairness) [28].

\subsection{Digital government in Western Balkan}

The situation around digital government in the Western Balkans countries varies and there are also similarities, such as challenges and opportunities [29, 30]. A paradox surrounding the digitalization of the region is that undeveloped countries are pushed to do more at the same time as the budget to do so is smaller. Because of the region's economic situation, the Western Balkans face challenges in both e-government and good governance i.e. lack of transparency, social inclusion, efficient public service, technical skills, high cost technology and inefficient government regulations [30]. However, the region has managed to develop rapidly in the last five years. But still, the region has a long path left to walk. Even if the Western Balkans (Croatia excluded) do better than most states, the region is still behind the top and lags in several aspects. The comparison is divided into three stages 1 . Transparency 2. Participation and 3. Collaboration. 
The region is strongest in stage one but lags in stage two and even more in stage three [29].

Even though the countries might have a vibrant civil society, there is no centralized partnership between the NGOs and the state for example in Bosnia and Herzegovina. Another aspect that is brought up as a challenge for e-participation and open government is the lack of trust [29]. According to the regularly UN report the Western Balkan countries are categorized as having a high e-Government Development Index, which places the region in the second-best level out of four. However, this level is where most of the 193 UN member nations are placed [31]. A study focusing on smart growth i.e. higher education, technological readiness, business sophistication and innovation in Albania, North Macedonia, Montenegro, and Serbia shows that the Western Balkan states lag behind the EU-28 countries [32]. There are discussions on e-readiness including for example fixed-broadband Internet subscriptions, Inter-net bandwidth and mobile-broadband subscriptions. Smart growth is seen as a way for opening up for possibilities to enter the EU. There is a digital divide both in the countries and between the Western Balkans and developed countries in the EU. Different vulnerable groups, rural areas and more are digitally excluded in the Western Balkan region [33].

The Balkan Barometer, a survey performed by the Regional Cooperation Council [34], shows that $26 \%$ of the respondents are not using the Internet at all, and $13 \%$ get personal documents online. According to the study, North Macedonia has the highest use of internet, but only $4 \%$ of the population use governmental e-services. The trust in governments is generally low among the countries and the survey shows that $77 \%$ consider political parties corrupt and $68 \%$ consider the parliament as corrupt. There is also low trust in digital government as $45 \%$ are concerned about data security, and only $38 \%$ trust government and audit authorities. Thus, the context for digital government in the Western Balkan states differ from most western countries.

\subsection{Analyzing digital government in the best practices from Western Balkan}

The best practices of digital government provided by the professionals from the countries of the Western Balkans are here set in relation to stage models in combination with public values. As these diverse, yet cohesive, set of countries build on a mix of ethnic-, economic-, and social values, Lee's [6] stagemodel structures the analysis of the presented best practices.

By doing so, we adhere to the model of Rooks, Matzat, and Sadowski [26] who, through their empirical study of Dutch municipalities, delimit the work of
Lee [6] to encompass four stages: Information provisioning; Requests for permits and documents; Personal service delivery, and; E-Democracy. Common with the models presented in the section above, Information provision-ing refers to the situation wherein information is pushed one-sidedly to the citizens lacking feedback between citizens and government. Requests for permits and documents allow for interaction between citizens and government that relate to a single case, i.e., applying for a sector-specific service. Indicative for Personal service delivery is a more comprehensive interaction wherein the use of technology is streamlined and where the citizen is actively engaged in information transactions with public service provisioning. The last phase combines what Lee [6] denotes as the stages of morphing and e-governance into $e$-democracy. Herein, citizens can be active and participate in the formulation of policies and there is a horizontal and vertical integration to focus on the end-user that actually stretches beyond the participatory meaning of digital democracy.

At all these stages, different values can guide the practices, and thus there is a variation among the best practices presented. Thus, we add Bannister and Connolly's [28] distinction that the value orientation of digital government can be based in a duty, a service focus or orientation towards social integration. We see duty-oriented values as traced through rule by the law and practices developed to facilitate certain limited duties. The service-oriented values refer to practices focusing on the end-users needs and demands. Finally, practices that strive for interaction and collaboration are set in the category of socially-oriented values. Taken combined, we created an analytical framework as illustrated in table 1 .

Table 1. Analytical framework

\begin{tabular}{|l|l|l|l|}
\hline \multirow{2}{*}{$\begin{array}{l}\text { Stage of e-gov- } \\
\text { ernment devel- } \\
\text { opment }\end{array}$} & \multicolumn{3}{|c|}{$\begin{array}{l}\text { Value guiding the best practices } \\
\text { of e-government }\end{array}$} \\
\cline { 2 - 4 } & Duty & Service & Social \\
\hline $\begin{array}{l}\text { 1. Information } \\
\text { provisioning }\end{array}$ & & & \\
\hline $\begin{array}{l}\text { 2. Requests } \\
\text { within silos }\end{array}$ & & & \\
\hline $\begin{array}{l}\text { 3. Service deliv- } \\
\text { ery }\end{array}$ & & & \\
\hline 4. E-democracy & & & \\
\hline
\end{tabular}

\section{The best practices of e-government in Western Balkan}

This section presents the included states and best practices, to analyze them through the model presented above. 


\subsection{The states represented by the participants}

The six included states are: Albania, Bosnia and Herzegovina, Kosovo, Montenegro, North Macedonia and Serbia. These Western Balkans countries have built a democratic façade but in reality, political elites rely on informal structures, clientelism and control over the media [35]. The welfare systems in Western Balkan states follow a pattern of post-communist welfare state regimes, except from Albania and Kosovo that have much lower coverage of social assistance and social insurance [36].

Table 2: States in the sample

\begin{tabular}{|l|l|l|l|}
\hline Country & $\begin{array}{l}\text { Popula- } \\
\text { tion (mil- } \\
\text { lion) }\end{array}$ & $\begin{array}{l}\text { Year of } \\
\text { indep- } \\
\text { endence }\end{array}$ & $\begin{array}{l}\text { GDP/ } \\
\text { capita } \\
\text { (US dol- } \\
\text { lar) }\end{array}$ \\
\hline Albania & 2.9 & $\begin{array}{l}1946, \text { as a } \\
\text { democ- } \\
\text { racy 1992 }\end{array}$ & 5448 \\
\hline $\begin{array}{l}\text { Bosnia and } \\
\text { Herzegovina }\end{array}$ & 3.2 & 1992 & 6066 \\
\hline Kosovo & 1.8 & 2008 & 4458 \\
\hline Montenegro & 6.2 & 2006 & 8846 \\
\hline $\begin{array}{l}\text { North Mace- } \\
\text { donia }\end{array}$ & 2.1 & 1991 & 6058 \\
\hline Serbia & 6.9 & 2006 & 7409 \\
\hline
\end{tabular}

Albania became independent in 1946 but it was not until 1992 that the country became a democratic state. Today the President is the head of state and has the legislative power while the Prime Minister is the head of the government in a multi-party system where the executive power is exercised. This political system was adopted in 1998 after having a socialist republic system. Albania had their first free election in 1991. Since then the power has shifted between the socialistic and democratic party [37,38]. Albania replaced the universal social welfare provision based on full employment under a centralized state socialism, by a system of comprehensive social insurance [38].

Bosnia and Herzegovina $(\mathrm{BiH})$ has a complex and asymmetric multi-ethnic governance structure including two entities with their own constitution, Republika Srpska (RS) and Federation of Bosnia (FBiH). The presidency consists of three members from each ethnic group (one Bosniak and Croat from the $\mathrm{FBiH}$, and one Serb from RS), the role head of the state shifts between these three members. BIH is a parliamentary representative democracy, where the executive power resides in the council of ministers and its chairman the Prime Minister. Legislative power is exercised both by the council of ministers and the parliamentary assembly $[37,38]$.
Kosovo, the country that most recently declared itself independent, is a multi-party parliamentary representative democratic republic with parliamentary elections every four year. The President is the head of state while the Prime Minister is the head of the government and has the executive power. The legislative power is exercised by both the government and the parliament. [37] In Kosovo the dominant model of welfare is based on a universal entitlement to social assistance and flat-rate non-contributory pensions. The welfare system has been built from scratch, while in the other states the preexisting entitlements to social insurance and other aspects of social welfare systems have been maintained [39].

Montenegro, North Macedonia and Serbia all have a similar governmental system where the Prime Minister is the head of a multi-party government and the head of state is the President. Executive power is exercised by the government while the legislative power is exercised by the government and the parliament. [37, 38] Their welfare forms have been modified over time, radical reforms have been introduced for example pension systems in Macedonia, but not in Serbia, Montenegro or Bosnia and Herzegovina [39].

This shows that on an overall level the states have similar core characteristics. Serbia and Montenegro stand out as larger in size and also with a higher economic standard on average. These pre-conditions give better resources for both welfare reforms and probably also for the e-government reforms. Conflicts, wars and transitional recessions have resulted in a process of deindustrialization in several Western Balkan states, which has made the development of the welfare state into reverse [39]. All the states have adopted hybrid welfare regimes consisting of the legacy of previous socialist systems, transition changes and associated deindustrialization [39].

To conclude, all these states have and are still facing fundamental and institutional changes were digitalization plays a crucial part for reformations as the best practices presented here will illustrate.

\subsection{The best practices}

In total, the interactive research process generated 28 illustrations of best practices. The wide array of public services are analyzed according to the model presented in table 1, we get the picture of table 3 .

\section{Table 3. Types of Best Practices}

\begin{tabular}{|l|c|c|c|c|c|c|c|}
\hline \multirow{2}{*}{ Best practice } & \multicolumn{3}{|l|}{ Stages* } & \multicolumn{3}{l|}{ Value orient. } \\
\cline { 2 - 7 } & 1 & 2 & 3 & 4 & Duty & Ser. & Soc. \\
\hline Albania & & & & & & & \\
\hline
\end{tabular}




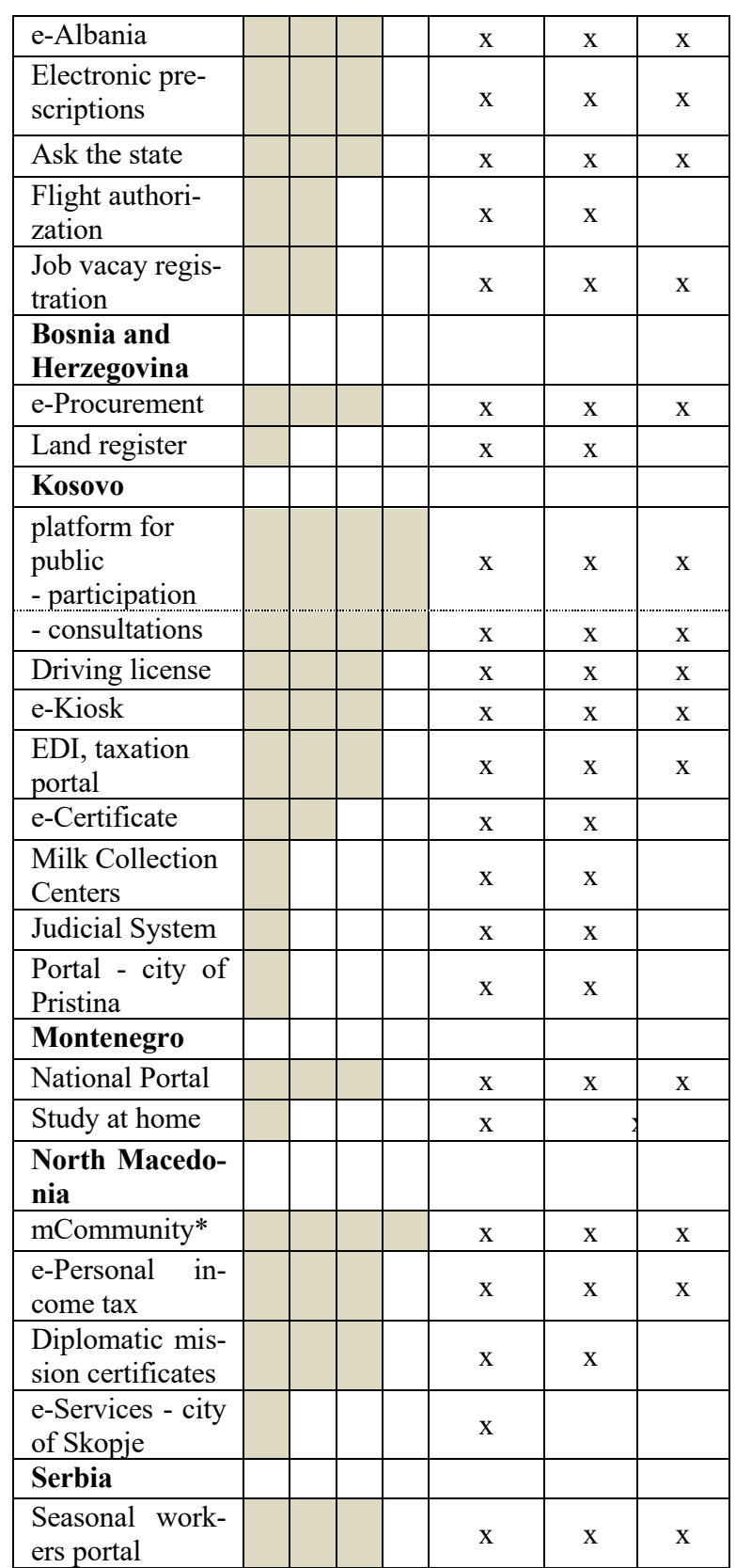

$*=$ Non-governmental initiative. 1 . Information provisioning, 2. Requests within silos, 3. Service delivery, 4. e-democracy.

Two of the included Albanian best practices are on applying for different forms of permits. The national system for electronic prescriptions of medications is indicative for a service that facilitate citizen to government interaction as the service allows citizens to request medications, wherein a doctor acts as an intermediary between the user and pharmacies. eAlbania acts primarily as a service catalogue and repository for forms by coordinating information and services from various governmental agencies into a "one-stop- shop." Hence, citizens can also endow taxes or other types of service fees through the portal.

The two accounts of best practices in Bosnia and Herzegovina relate to public procurement and the social interaction are with firms rather than citizens. The land register service provides permits for other off-line services.

The participants from Kosovo provided most and more interactive and innovative best practices. These best practices show more evident accounts of services and aim at increasing citizen participation. As a result, the platform for public participation and consultations also not only sought to promote collaboration but also contained interactive catalogues of proposals in which the citizens could vote or promote ideas or initiatives primarily aimed at solving issues relating to infrastructure (e.g., roads, lighting, playgrounds, etc.). This indicates that citizens are not only reporting problems, but also become directly involved in policy formation and community services. The practice of the e-Kiosk service was first developed as a mean to print forms and certificates, but has developed into a more integrated service wherein the citizen can pay her taxes, indicating that the adding of new layers upon existing services act to further maturity and extending eGovernment provisioning through existing means.

In Montenegro, the eGovernment portal contain over 315 services [40] that relate to a variety of sectors. However, the bulk of which relates to sector specific services. One interesting addition of services was the portal "Study at home" that was set-up to facilitate e-learning for younger pupils amidst the spread of Covid-19, and consequently the lockdown of schools in Montenegro. The portal acts to relay class curricula and holds course videos, thereby showing that public e-services can be used as a quick-fix to mitigate the social impacts of quarantining.

Seen from the best practices of North Macedonia, as with other countries, the services aimed at providing different types of forms or certificates. Community is a first try of providing interactive means for citizens to raise initiatives and report problems. However, as noted by the participant in our course, the service had a low uptake among governmental actors, thereby impeding integration.

In Serbia, the "Seasonal workers portal" is a combined portal and mobile application in which seasonal workers are given information about work related issues and opens for interactions with various agencies and to endow fees. Most of the services provided in all states facilitate information provisioning or the distribution of forms, that most often have to be printed and submitted. These services are based on duty orientated values and rule by the law. In this sense, e-government is a pre-requisite for government, 
as forms still need to be printed, stamped, and handled within the physical boundaries of bureaucracy. There is, however, a surprising number of services that emphasize the interaction with citizens or businesses. In the forthcoming sections, we provide a more in-depth description of selected best-practices, as to illustrate the diversity found.

\subsubsection{A more advanced best practice: eGovern- ment Portal of Montenegro}

One of the most advanced best practices according to the discussions among the participants and our analysis is the eGovernment Portal of Montenegro. It is an online platform on national and local level, capturing over 580 services under the jurisdiction of 50 institutions. The portal compiles various services for citizens, businesses, and public administration. The portal is available in English and Serbian (both Cyrillic and Latin alphabet). However, in the English version, there is only general links and there are not as many options as in the Serbian version, where you among other services can access medical prescriptions and test results [40].

\section{Illustration 1. Services in eGovernment Portal of Montenegro}


For individuals there are service options on: business and work (poslovanje), documents (dokumenti), health (zdravlje), housing and environment (uređenje prostora, izgradnja objekata), registries and statistical research (statisticka istrazivanja podataka), law and order (javne nabavke), education (obrazovanje), finance (finansije), work (rad), tourism (turizam), citizen report (prijave građna), youth and sport (mladi i sport). What is interesting is that it both provides personal services and general information, like statistics and law and order. This platform is an online service for all citizens in Montenegro. You need to sign in with your health card number and your pin code to login to the system. This service is showing the most advanced social value orientation, by its easy access, all- embracing approach to governmental services and end-user-oriented design.

\subsubsection{Land register in Bosnia and Herzegovina}

The second illustration that was seen as most useful among the participants was the digital land register in Bosnia and Herzegovina, where you can view plots of land and who it belongs to. The website is only available in Bosnian [41].

The first page welcomes you and presents how the Federal Administration for Geometric and Property data works and provides instructions on how to search land or use the Geoportal. The services are based on Google maps. It shows if the land plot is divided into one or several beneficiaries. The map can zoom in on specific areas.

\subsubsection{Mobile driving license in Kosovo}

The third best practice chosen was the world's first nation-wide mobile driving license service. Introduced in 2018, the citizens of Kosovo can use an app to show their driver's license on their smartphones. To verify the license, public authorities need to use a matching app on their smartphone. This mobile driving license can be used as an ID wallet for a variety of different IDs, such as mobile health care or digital identity card. [42]

The app is based on the VeriGO DriveID mobile driver's license platform by Veridos. According to their website, the first step is to start the app and it will automatically display personal information. The officials can verify the license simply by reading the $\mathrm{QR}$ code with their smartphone.

Illustration 2. Instructions step by step for Mobile driving license

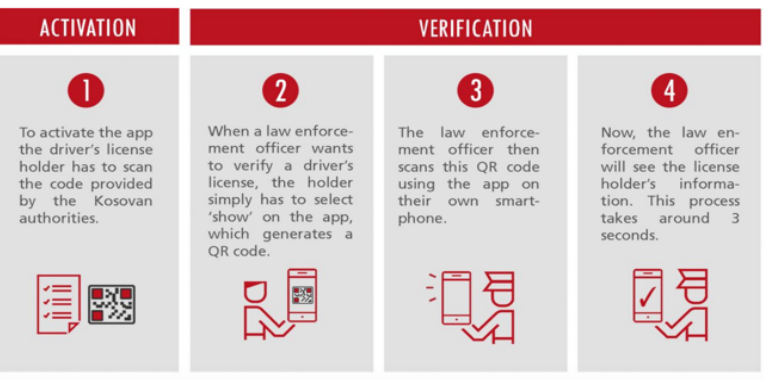

This app makes it possible to access and identify yourself, without having to carry your ID card or wallet. However, this app is only useful if citizens accept and use e-services. This means that everyone needs to use it for it to be an effective and inclusive digital tool, including groups in the society who usually do not use digital tools. 


\section{Analysis and Conclusions}

These best practices indicate that the illustrations, in line with most other states, are not fundamentally changing into a digital government structure. However, there are innovative ambitions, lots of energy, and a sharing approach giving hope for sustainable digital government.

The best practices presented above illustrate that most of the e-government services provided among the Western Balkan states are still preconditions for other offline services, like permits and information provision to conduct other services. At first, there are some best practices that look advanced and integrative, but at a further analysis, they are not fully meeting the bestowed expectations. Our analysis of in what way eservices have developed in Western Balkans matches the results of Millard et al. [29].

The countries included in this study provide egovernment services to a similar extent. The most evident accounts of which relate to internet portals where the citizen can access information, "pull" sector-specific services, order different types of certificates, or pay taxes. In line with most other more mature governmental structures, there are few new institutional arrangements for e-government. Similar to the models developed for more mature contexts for digital government development $[5,6,7]$, our selection of countries shows the same tendency to follow the stages models. It is worth noting that these models, including the model of Rooks, Matzat and Sandowski [26], are instruments for measuring e-government progress.

Despite these limitations, this analysis indicates a clear path dependency in how value-ordination relates to the stage model, and of how e-government progress gradually. Duty-oriented values guide the stages of information provision and requests within a silo or governmental division. The stage of e-service delivery is based on values that are oriented to services, and to meet the needs of the end-user, but still also based on the duties as citizen. The few examples of what is called e-democracy in this model build on social-oriented values since it focuses on horizontal and vertical integration.

Based on the discussions with the participants we would argue that the underlying reason for this 'copypaste' scheme of e-government development relates to a lack of resources; financially and regarding competences to think outside the box concerning the building and maintenance of new institutional arrangements that act as complements to existing public sector arrangements. It is evident that there are no shortcuts to progress into advanced digital government services. There is a need to start sorting out the needs for information and meet the requests raised with each silo of government and provide services within the same area. However, there are illustrations of the ability to take steps in horizontal and vertical integration in the interest of service-oriented values as exemplified by the mobile driving license service introduced in Kosovo. The process seems to have progressed quickly, yet all stages are passed during the development process almost as path dependency of digital government.

As with Kosovo, the country has a more developed and comprehensive welfare system compared to the other states in the sample and it is also the most recent state. The best practices chosen by the participants from Kosovo also exhibited more advanced forms of features and deeper integration within different sectors of government when compared to other Western Balkan countries. Here the welfare schemes grow, and so does government responsibility for service provisioning and the need for cross-sectoral integration within the different arms of government and its agencies. The state has more similarities with EU and are rapidly developing both regarding e-government and in other terms.

This study indicates a need to see e-government in more diverse contexts and it also suggests that it would be fruitful for further research to study how welfare schemes impact e-government maturity.

\section{Acknowledgement}

We are grateful for the Swedish Institute for funding and all participants for their input, ideas and discussions on e-government practices.

\section{References}

[1] H. Margetts and A. Naumann. "Government as a platform: What can Estonia show the world.", University of Oxford, 2017.

[2] N. Heller. "Estonia, the digital republic". The New Yorker, 2017.

[3] European Commission, https://ec.europa.eu/digital-single-market/en/content/open-democratic-and-sustainable-digital-society, (access 2020-07-11).

[4] F. Bannister. "In Defence of Bureaucracy: Governance and Public Values in a Digital Age", Beyond Bureaucracy. Cham, Springer, 2017, pp. 27-47.

[5] K. Layne and J. Lee. "Developing fully functional E-government: A four stage model", Government Information quarterly, 18(2), 2001, pp. 122-136.

[6] J. Lee. "10 year retrospect on stage models of e-Government: A qualitative meta- synthesis", Government Information Quarterly, 27(3), 2010, pp. 220-230.

[7] B. Klievink and M. Janssen. "Realizing joined-up government - Dynamic capabilities and stage models for transformation", Government Information Quarterly, 26(2), 2009, pp. 275-284. 
[8] T. Brannan, C. Durose, P. John and H.Wolman. "Assessing Best Practice as a Mens of Innovation", Local Government Studies, 34(1), 2008, pp. 23-38.

[9] The Swedish Institute, https://si.se/en/apply/leadershipprogrammes/si-summer-academy-for-young-professionals-sayp-western-balkans/, (access 2020-06-30).

[10] Ekonomistyrningsverket, https://www.esv.se/statsliggaren/regleringsbrev/?rbid $=20440$, (access 2020-07-01)

[11] Linköping University, https://liu.se/en/article/segrid (access 2020-06-30).

[12] M. Elg, I. Gremyr, A. Halldorsson and A. Wallo. "Service action research: review and guidelines", Journal of Services Marketing (preview), 2020, pp. 87-99.

[13] EU Commission. The Digital Economy and Society Index. 2020

[14] Begripsam. Svenskarna med funktionsnedsättning och internet 2019. 2019.

[15] Rothstein, B. and S. Steinmo, (Eds.). Restructuring the welfare state: political institutions and policy change. Springer, 2016.

[16] Fountain, J. E. Building the virtual state. Information technology and institutional change. Brookings Institution Press, 2001.

[17] A. Cordella, A. Paletti, S.A. Chun, N.R. Adam and B. Noveck. "ICTs and value creation in public sector: Manufacturing logic vs service logic". Information Polity, 23(2), 2018, pp. 125-141.

[18] K. Siau and Y. Long. "Synthesizing e-Government stage models - a meta-synthesis based on meta-ethnography approach", Industrial Management \& Data Systems, 105(4), 2005.

[19] D. Coursey and D.F. Norris. (2008). "Models of e-government: Are they correct? An empirical assessment", Public Administration Review, 68(3), 2008, pp. 523536.

[20] M. M. Nielsen (2016). "The Role of Governance, Cooperation, and eService Use in Current eGovernment Stage Models", Proceedings of the HICSS-49, 2016, pp. 2850-2860.

[21] Hiller, J. S. and F. Bélanger. "Privacy strategies for electronic government”. A.M.A. \& M.G. E. (Eds.), Egovernment 2001. Lanham: Rowman \& Littlefield. 2001.

[22] F. Bélander and J. S. Hiller. "A framework for e-government: privacy implications", Business Process Management Journal, 12(1), 2006, pp. 48-60.

[23] A. K. Normann, J. Lee, T. Mettler and M. J. Moon. "Ten Misunderstandings about Maturity Models". Proceedings from the $21^{\text {st }}$ Annual International Conference on Digital Government Research, Seoul. 2020.

[24] P. Joshi and S. Islam. "E-government maturity model for Sustainable e-Government Services from the Perspective of Developing Countries", Sustainability, 10(6), 2018, pp. 1882.

[25] K. V. Andersen and H. Z. Henriksen. "E-government maturity models: Extensions of the Layne and Lee model", Government Information Quarterly, 23(2), 2006, pp. 236-248.
[26] G. Rooks, U. Matzat and B. Sadowski. "An empirical test of stage models of e-government development: Evidence from Dutch municipalities", Information Society, 33(4), 2017, pp. 215-225.

[27] T. B. Jørgensen and B. Bozeman. "Public Values", Administration \& Society, 39(3), 2007, pp. 354-381.

[28] F. Bannister and R. Connolly. "ICT, public values and transformative government: A framework and programme for research". Government Information Quarterly, 31(1), 2014, pp. 119-128.

[29] J. Millard, L. Thomasen, G. Pastrovic, and B. Cvetkovic, B. "A roadmap for e-participation and open government: empirical evidence from the Western Balkans", ICEGOV '18: Proceedings. 2018, pp. 191-198.

[30] V. Madzova, K. Sainoski, L. Davacev. "E-Government as an Efficent Tool towards Good Governance: Trends and Comparative Analysis throughout Worldwide Regions and within West Balkan Countries", Balkan Social Science Review, 1, 2013, pp. 157-174.

[31] The UN. United Nations E-Government Survey 2018 Gearing E-Government to support transformation towards sustainable and resilient societies. 2018.

[32] O. Kostoska and I. Hristoski. (2017). "ICTs and innovation for competitivness: Evidence for Western Balkans vis-à-vis the European Union", Zbornik Radova Eknomskog, 35(2), 2017, pp. 487-518.

[33] D. Mitrovic. "Broadband Adoption, Digital Divide. And the Global Economic Competitiveness of Western Balkan Countries", Economic Annals, LX(207), 2015, pp. 95-116.

[34] Region Cooperation Council. Balkan Barometer 2019: Public Opinion Analytical Report. 2019.

[35] M. Kmezic. "Rule of law and democracy in the Western Balkans: addressing the gap between policies and practices", Southeast European and Black Sea Studies, 20(1), 2020, pp. 183-198.

[36] J. Aidukaite. "Welfare reforms and socio-economic trends in the 10 new EU member stated of Central and Eastern Europe", Communist and Post-Communist Studies, 44(3), 2011, pp. 211-219.

[37] WHO, https://www.who.int/, searched on each of the countries, (accessed 2020-06-28).

[38] The World Bank, country information, https://www.worldbank.org, (accessed 2020-06-28).

[39] Bartlett. W. "The Political Economy of Welfare Reform in the Western Balkans." Poverty and Exclusion in the Western Balkans. Springer, 2013. Pp. 245-259.

[40] eUprava, portal eUprave Crne Gore, https://www.euprava.me/, (accessed 2020-07-01).

[41] Federalna uprava za geodetske i imovinsko-pravne poslove, https://www.katastar.ba, (accessed 2020-0701).

[42] Veridos, https://www.veridos.com/en/news/kosovorolls-out-the-worlds-first-mobile-drivers-license279.html, (accessed 2020-07-01). 